\title{
In Between Democracy and Secularism: The Case of Turkish Civil Society
}

\section{Salim Cevik \& Hakki Tas}

To cite this article: Salim Cevik \& Hakki Tas (2013) In Between Democracy and Secularism: The Case of Turkish Civil Society, Middle East Critique, 22:2, 129-147, DOI: 10.1080/19436149.2013.783534

To link to this article: http://dx.doi.org/10.1080/19436149.2013.783534

曲 Published online: 07 May 2013.

Submit your article to this journal $\pi$

LII Article views: 513

Q View related articles ๘

4 Citing articles: 1 View citing articles 


\title{
In Between Democracy and Secularism: The Case of Turkish Civil Society
}

\author{
SALIM CEVIK $^{*} \& \mathrm{HAKKI}_{\mathrm{TAS}}^{* *}$ \\ *Bilkent University, Turkey \\ ** Ipek University, Turkey
}

\begin{abstract}
Since 2011, the Arab uprisings, signaling a new wave of political mobilization, have restored belief in the potential for civil society to make democratic openings. Nevertheless, the academic literature up to the present has attributed the enduring authoritarianism in the Middle East region to the weakness or dominantly Islamist nature of civil society and promoted the development of secular platforms. This article argues that the discussion about civil society is misplaced, and the democratic potential of civil society is not related to its being Islamic or secular, but rather to its attachment to the state. For this purpose, it examines the emergence of a secularist civil societal current in Turkey with special focus on one of its major manifestations, the Republic Rallies in 2007.
\end{abstract}

Key Words: AKP; civil society; democratization; EU-accession; Kemalism; Republic Rallies secularism; state ideology; Turkish nationalism; Turkey; anti-Westernism

In twenty-first century Turkey, the catch phrase, 'We do not need democracy, but the Republic, ${ }^{1}$ has been utilized heavily in secularist ${ }^{2}$ circles by those who feel threatened by the liberal reforms undertaken on the path to Turkey's accession to the European Union. ${ }^{3}$ The secularist establishment, the forerunner of Westernization, now fears that further democratization will erode the unitary secular character of the regime, both by granting

Correspondence Address: Salim Cevik, Department of Political Science, Bilkent University, 06800 Bilkent Ankara, Turkey. Email: salimcevik@yahoo.com. Hakkı Taş, Department of Political Science, Ipek University, Turan Güneş Bulvari 98-3, Ankara, Turkey. Email: hakkitas@altinkoza.edu.tr

${ }^{1}$ N. Akman (2005) Emekli General Nejat Eslen: Demokrasi, Türkiye'nin öncelikli meselesi değil [Retired General Nejat Eslen: Democracy is not a priority for Turkey], Zaman, July 18, 2005; and M. Akyol (2005) Ulusalcılarımızın Çıkarları [The interests of our nationalists], Radikal, September 30, 2005.

2 Secularism has different implications and conceptualization in different contexts. The dominant interpretation of secularism in Turkey is 'assertive secularism' which aims to end the public role of religion. Throughout our discussion of Turkish secularists, we refer to this dominant version of secularism and to the groups that adhere to assertive secularism. For a thorough discussion of Turkish secularism in comparison with the secularism in the United States and France, see A. Kuru (2009) Secularism and State Policies Toward Religion: The United States, France and Turkey (Cambridge: Cambridge University Press).

${ }^{3}$ H. Altınay \& K. Nicolaidis (2008) Why the European Union strengthens Turkish secularism, Open Democracy, August 3, 2008. Available at http://www.opendemocracy.net/article/the-european-union-and-tur key-strengthening-secularism, accessed January 5, 2009.

(C) 2013 Editors of Middle East Critique 
more rights to ethnic and religious minorities and by clearing the path for political Islam. Manifestations of this fear and reactions to it range from anti-EU conferences to civil societal demonstrations calling for the army to topple the government. ${ }^{4}$

Turkey's recent paradox framed as 'secularism versus democracy' is an illuminating case for the broader Middle East region, where the promotion of a secular civil society is taken as a sine qua non for democratization. ${ }^{5}$ As a Muslim-majority country, Turkey's relative success with democracy mostly has been attributed to its secular character and celebrated as an exemplary model for the region. ${ }^{6}$ However, it is now the Turkish secularists themselves who have troubles in reconciling democracy and secularism.

In examining the case of Turkish civil society, this article examines the validity of the correlation between secularism and democracy. Since its early formulation, civil society has come to represent different meanings. For example, Edward Shils points that, despite the varying and changing meanings of the concept, three central characteristics have been sustained since the eighteenth century: 'The distinction and the independence of society from the state, the rights of individuals, a constellation of many autonomous economic units or business firms acting independently of the state and competing with each other. ${ }^{7}$ In parallel, we will rely on Ernest Gellner's definition of civil society as a

set of diverse non-governmental institutions which is strong enough to counterbalance the state and, while not preventing the state from fulfilling its role of keeper of the peace and arbitrator between major interests, can nevertheless prevent it from dominating and atomizing the rest of society. ${ }^{8}$

In the case of Turkish civil society, this article aims to reveal the roots of the insistence on equating secularism and democracy and its repercussions on Turkish democratization, a project traditionally promoted by the supporters of a secular civil society. In order to demonstrate the possible tensions between further democratization and Turkish secularists, we will examine the development of a secularist, anti-Western and promilitary civil society in contemporary Turkey. The Republic Rallies, which were the first and most important manifestation of this secularist civil society in 2007, will be taken as a case study in order to analyze the democratic potentials of these civil society groups. Throughout the discussion, we will try to demonstrate that the democratic potential of a civil society is not related to its being Islamic or secular but rather to its detachment from the state and state ideology.

\section{Civil Society and Secularization in the Middle East}

The concept of 'civil society' has dominated the democratization literature increasingly since the 1980s. Many scholars consider a vibrant civil society as one of the prerequisites

\footnotetext{
4 'Ordu Göreve' DGMlik oluyor ['Army, Do Your Duty' brought to the National Security Court], Hürriyet, November 4, 2003.

5 S. Berman (2003) Islamism, Revolution and Civil Society, Perspectives on Politics, 1(2), pp. 257-272.

${ }^{6}$ B. Toprak (2005) Islam and Democracy in Turkey, Turkish Studies, 6(2), pp. 167-186; and S. Lakoff (2004) The Reality of Muslim Exceptionalism, Journal of Democracy, 15(4), pp. 133-139, p. 134.

7 E. Shils (1991) The Virtue of Civil Society, Government and Opposition, 26(1), pp. 3-20, p. 4.

${ }^{8}$ E. Gellner (1994) Conditions of Liberty: Civil Society and Its Enemies (New York: Penguin), p. 5.
} 
to the consolidation of democracy. ${ }^{9}$ This concept, which is rooted in eighteenth-century Western political philosophy, made its greatest success in Eastern Europe, where civil organizations played a crucial role in the overthrow of the socialist regimes in the region with international political support. After this surprising achievement, the concept first was 'reimported' 10 into Western political literature and then was adopted by the rest of the world as a magic cure for all the ills in regions where oppressive states prevailed, such as Latin America, the Middle East and Southeast Asia.

The revival of this concept as the counterpart of the state became the catalyst of a presumption among some policy-makers and political scientists: If a robust society could be established, then this would pave the road to the weakening of state coercion and ultimately to democratization. Establishing or strengthening civil society via the financing of nongovernmental organizations (NGOs) became a quick fix for policy makers and international donors to achieve consolidation of democracy. The proliferation of NGOs in quantity is considered as the burgeoning of independent civic activity and perhaps the source of peaceful democratic change, akin to the prodemocracy movements that emerged in Eastern Europe in the 1980s. ${ }^{11}$ In this line, civil society became an important topic on the checklist for democratic transition, and the blame was put easily on the lack of civil society in the regions that missed the third wave of democratization.

This early enthusiasm lasted briefly. After the initial excitement was gone, many scholars started to question the real impact of civil society in these political changes and claimed that the role attributed to civil society is highly overemphasized. ${ }^{12}$ 'After reaching soaring and unprecedented popularity in the last two decades, the concept of civil society is currently the object of considerable scrutiny, cynicism, and even disdain. ${ }^{13}$ However, the concept still enjoys an explanatory power when it comes to studies on Middle Eastern authoritarianism. This emphasis is not likely to wither away, because the recent Arab Spring once again has focused attention on civil society and on the new organizational venues that the technological developments made possible. Striking failures of the Middle East to experience democratic transition in 1991-2010 were linked with the alleged absence of civil society in the region. ${ }^{14}$ Moreover, normative assumptions of Islam's

\footnotetext{
9 There exists an expansive literature now on the necessity of an active civil society for democratic consolidation. Some of the most important contributions are from L. Diamond (1994) Rethinking Civil Society: Toward Democratic Consolidation, Journal of Democracy, 5(3), pp. 4-17; L. Diamond (1999) Developing Democracy Towards Consolidation (Baltimore: Johns Hopkins University Press); Gellner, Conditions of Liberty; J. J. Linz \& A. Stepan (1996) Problems of Democratic Transition and Consolidation: Southern Europe, South America, Post-Communist Europe (Baltimore: The Johns Hopkins University Press); R. Putnam (1993) Making Democracy Work: Civic Traditions in Modern Italy (Princeton: Princeton University Press); and M. Walzer (1992) The Civil Society Argument, in: C. Mouffe (ed.) Dimensions of Radical Democracy: Pluralism, Citizenship and Community, pp. 89-108 (London: Verso).

${ }^{10}$ F. Ibrahim \& H. Wedel (1997) Introduction, in: F. Ibrahim \& H. Wedel (eds) Ortadoğu'da Sivil Toplumun Sorunlart [Problems of civil society in the Middle East], pp. 11-28 (Istanbul: Iletişim), p. 12.

11 A. Hawthorne (2004) Is Civil Society the Answer?, Carnegie Papers, 44 (Washington D.C.: Carnegie Endowment for International Peace), p. 5.

12 C. Tempest (1997) Myths from Eastern Europe and the Legend of the West, Democratization, 4(1), pp. $132-44$.

13 O. G. Encarnación (2006) Civil Society Reconsidered, Comparative Politics, 38(3), pp. 357-376, p. 357.

14 A. Abootalebi (1998) Civil Society, Democracy and the Middle East, Middle East Review of International Affairs, 2(3), pp. 46-59. However, for an alternative view, see the articles guest edited by M. Valbjorn \&
} 
incompatibility with civil society dominate the relevant studies. Referring to the origins of the concept, for instance, Şerif Mardin declares civil society as a Western dream that would not translate into Islamic terms. According to Mardin, in the Muslim world, society waits for the 'just prince' to initiate reforms and to take control of societal development rather than mobilizing itself independently. ${ }^{15}$ In accordance with traditional Orientalism ${ }^{16}$ that conflates the East with passivism and fatalism, Middle Eastern societies are understood to be constituted of 'people ... [who] as a whole tend to consider life as a game of chance.' In this view, 'one has no alternative but to suffer the inevitable and basically negative vicissitudes of life.' 17

An extensive collaborative project led by Augustus Richard Norton, whose findings first appeared in a special issue of the Middle East Journal (MEJ), ${ }^{18}$ and later were published as an expanded two-volume book, ${ }^{19}$ challenged the Orientalist postulates and demonstrated that Middle Eastern societies are indeed quite active, especially given the authoritarian political settings in which they operate. Norton's study quickly become the conventional wisdom in the academic studies of civil society in Middle East. ${ }^{20}$ This also was paralleled by an increasing interest of policy-makers and political donors in civil society, 'as civil society assistance has constituted the linchpin of international MENA democracy promotion efforts. ${ }^{21}$ However, this early enthusiasm of scholars and policy-makers faded away as it became glaringly apparent that 'civil society has not yielded any results in pushing Arab states towards democratic transitions. ${ }^{22}$ Thus, the enduring problem of democratic failures in the Middle East still stands unexplained, and further complicated with the emprical findings of Norton's project. ${ }^{23}$

Footnote 14 continued

A. Bank in the special issue of Middle East Critique (2010) The Future of Middle Eastern Political Rule Through Lenses of the Past: Revisiting the (first) Era of Post-Democratization, 19(3), pp. $181-319$.

15 Ş. Mardin (1995) Civil Society and Islam, in: J. Hall (ed.) Civil Society: History, Theory, Comparison, pp. 278-300 (Cambridge: Polity Press).

16 Richard Norton rightly argues that this orientalist analysis can be traced back to Karl Wittfogel's influential work Oriental Society. Norton states that 'according to Wittfogel, absence of a civil society to counterbalance despotic power was a marker of oriental society, and it is this lacuna that lies at the heart of the orientalist analysis.' See A. R. Norton (1993) The Future of Civil Society in Middle East, Middle East Journal, 47(2), pp. 205-216, p. 212; and K. Wittfogel (1957) Oriental Despotism (New Haven, CT: Yale University Press).

17 M. Sariolghalam (1997) Prospects for Civil Society in the Middle East: An Analysis of Cultural Impediments, in: E. Özdalga \& S. Persson (eds) Civil Society, Democracy and the Muslim World, pp. 57-73 (Istanbul: Swedish Research Institute), p. 59.

18 Norton, Future of Civil Society.

19 A. R. Norton (ed.) (1995/1996) Civil Society in the Middle East (Leiden: Brill Academic).

${ }^{20}$ F. Cavatorta (2006) Civil Society, Islamism and Democratization: The Case of Morocco, Journal of Modern African Studies, 44, pp. 203-222.

21 S. L. Yom (2005) Civil Society and Democratization in the Arab World, Middle East Review of International Affairs, 9(4), pp. 14-33, p. 17.

22 Ibid

23 There is also an extensive and expanding literature that explains the democracy failures as the deliberate result of Western political involvement in the region. The formation of Middle East Information Project (MERIP) in 1971 has been a stimulus to the emergence of this alternative school of thought. Two academic journals, Middle East Report, published by MERIP and Middle East Critique, had been the two major avenues for the flourishing of this critical literature. For a wider and more historical analysis of Western involvement in the region see also J. Salt (2008) The Unmaking of the Middle East (Berkeley, CA: University of California Press). 
The secularist response to this puzzle has been the exclusion of Islamic civil activism from the definition of civil society. ${ }^{24}$ For instance, Ernest Gellner, who for long pointed to the strength of social life in the Muslim World, ${ }^{25}$ considers Islam as one of the "enemies of civil society.' In this view, traditional Muslim civil formations are samples of segmentary societies. They are neither voluntary nor libertarian and do not count for civil society. Moreover, Gellner finds parallels between Islam and Marxism on their monopoly of truth claims and considers both of them as enemies of civil society. According to Gellner, Islam still has a normative ideal that manifests itself in the intolerant character of the Islamic organizations, and Islam's resistance to secularism prevents the blooming of civil society. He claims that the Muslim world 'is marked by the astonishing resilience of its formal faith, and a merely weak, at best, striving for civil society. ${ }^{26}$

Some other scholars view civil society as a neutral category and accept the Islamic organizations as civil society; however, they question the democratic credentials of such formations. Richard Norton, whose study 'led to the demise of the myths on the fatalism of the Middle Eastern people, ${ }^{, 27}$ relates the prevalance of authoritarianism in the Middle East to the lack of civility and tolerance in the Islamic context and, thus, Norton claims that civil society in the Middle East may not necessarily help democratization, though he is hopeful that "civility can be learned. ${ }^{28}$ Questions on the democratic potentials of Islamic civil society organizations became to be questioned even more in the wake of 9/11. In a widely read article that aims to identify the roots of political failures in the Middle East, Fareed Zakaria points to the dominance of religious groups in social life and claims that 'for those who treasure civil society, it is disturbing to see that in Middle East, these illiberal groups [referring to religious groups] are civil society. ${ }^{29}$ Sheri Berman appears the most explicit voice of this line of argument, claiming that 'the growing strength of civil society [in the Arab world] boded ill rather than well. The expansion of civil society is an incubator of illiberal radicalism. ${ }^{, 30}$ Thus, religious organizations either would be excluded from the definition of civil society, as Gellner and Mardin did, or they would be claimed to be either insufficient, useless or even harmful for democratization, as Norton, Zakaria and Berman did.

The polemic about the role of Islam in Middle Eastern civil society has concrete implications framed in a paradoxical relation between the development of civil society and further democratization in the region. Accordingly, as the state liberalizes and leaves space for civil society organizations, this space is filled by Islamic organizations, which is no good for eventual democratization. Thus, the public sphere eventually is controlled by either the repressive state or Islamic civil society; finally leaving no hope that liberalization will end in democratization. Moreover, once the failure in democratization

\footnotetext{
${ }^{24}$ S. Zubaida (2001) Civil Society, Community, and Democracy in the Middle East, in: S. Kaviraj \& S. Khilnani (eds) Civil Society: History and Possibilities, pp. 232-249 (Cambridge: Cambridge University Press), p. 239.

25 E. Gellner (1981) Muslim World (Cambridge: Cambridge University Press).

${ }^{26}$ Gellner, Conditions of Liberty, p. 14.

27 G. Nonneman (2001) Rentiers and Autocrats, Monarchs and Democrats, State and Society: the Middle East Between Globalisation, Human Agency, and Europe, International Affairs, 77(1), pp. 141-162, p. 143.

28 Norton, Future of Civil Society, p. 214.

${ }^{29}$ F. Zakaria (2001) The Politics of Rage: Why Do They Hate Us?, Newsweek, October 15, 2001, pp. 22-40, p. 34 .

30 Berman, Islamism, Revolution, p. 266.
} 
of the Muslim world is attributed to the Islamic nature of its civil society and to Islam's resistance to secularization, the expected consequence of this argumentation would be to support secular groups and regimes at any cost, as in the case of Fareed Zakaria, who argues that the 'autocratic, corrupt, and heavy-handed' Arab rulers are 'still more liberal, tolerant, and pluralistic than those who would likely replace them.' ${ }^{31}$

Recent years have witnessed the emergence of a revisionist strand of studies on civil society activism in the Muslim world. Mostly concentrating on the Arab World, authors like Amaney Jamal and Francesco Cavatorta, among others, questioned this dominant narrative that equates secularism with democracy at the civil society level. ${ }^{32}$ It is also highly probable that the recent 'Arab Spring' will result in an increase of studies within this line. This article contributes to this revisionist account from a different case study and tackles the dominant narrative through its stronghold: the Turkish case.

The emphasis on secularism puts Turkey as a control case. The relative success of Turkish democracy and the myths about Turkey being the single secular state in the Muslim World seem to support the arguments that secularism-in the literal sense of the word-is essential for a democratic civil society in the Muslim world. Turkey is considered to be exceptional in the Middle East as neither the state nor Islamists per se dominate civil society. This exceptional position led some scholars to the conclusion that 'the more relevant implication of the Turkish experience is that Islamic beliefs may have to be overridden ${ }^{33}$ in order to achieve democratic consolidation. According to Binnaz Toprak, the Turkish experience demonstrates that 'a Muslim nation can establish, sustain and begin to consolidate a democratic form of government and a liberal conception of public life as long as its state distinguishes between religion and the public sphere,' and Turkey owes its unique position in the Muslim world to the secularization reforms in the early Republic. ${ }^{34}$

Nevertheless, the political developments in Turkey since 2002 enable us to revise the assumed links between civil society, particularism, secularization, and democratization. In the last decade, Turkish politics witnessed a booming of a very lively and powerful secular civil society with authoritarian and anti-democratic tendencies. The activism of these secular civil society organizations had reached their peak in 2007 , when struggles over presidential power had led to an increased politicization of the entire society.

\section{The Secularist Civil Society in Turkey: Non-governmental, but Pro-state}

Following the foundation of the Turkish Republic in 1923, Mustafa Kemal Atatürk initiated a series of reforms to build a homogeneous nation-state by eliminating ethnic and

${ }^{31}$ F. Zakaria (2004) Islam, Democracy and Constitutional Liberalism, Political Science Quarterly, 119(1), pp. 1-20, p. 2. In contrast, for a provocative thesis claiming that revival of Islam is prone to democratization, see J. L. Esposito \& J. O. Voll (1996) Islam and Democracy (New York: Oxford University Press).

32 A. A. Jamal (2007) Barriers to Democracy: The Other Side of Social Capital in Palestine and the Arab World (Princeton, NJ: Princeton University Press); M. L. Browers (2006) Democracy and Civil Society in Arab Political Thought: Transcultural Possibilities (Syracuse, NY: Syracuse University Press); Cavatorta, Civil Society, Islamism and Democratization; F. Cavatorta \& V. Durac (2011) Civil Society and Democratization in the Arab World: The Dynamics of Activism (New York: Routledge).

33 Lakoff, Reality of Muslim Exceptionalism, p. 134.

34 B. Toprak, Islam and Democracy, p. 169. 
religious differences under the guidance of a state-determined Turkish nationalism. These reforms, framed as Kemalism, targeted the creation of a new individual compatible with the Western model of state and society. The secularization process in the early republican period (1923-38) included not only some political and legal moves, such as the abolition of the caliphate and the adoption of Western legal codes, but also some alterations in public life, such as the acceptance of the Western hat and Western styles of clothing, and the change of the weekly holiday from Friday to Sunday. ${ }^{35}$

Until the transition to multi-party democracy in 1946, the Republican People's Party (CHP, Cumhuriyet Halk Partisi) ruled the country in a 'party equals state equals government' formula. Nevertheless, after the inaugural development of a market economy and the formation of professional associations in the 1950s, the subsequent two decades witnessed 'the civil societal development of syndicalism, leftist political movements, and the diffusion of printed material. ${ }^{36}$ Civil society organizations have proliferated and become more vocal in the post-1983 period, with the expansion of the export-oriented market economy, the arrival of private radio and television channels, and globalized communication networks. Nevertheless, the secularist NGOs with strong Kemalist identification rather appeared in the $1990 \mathrm{~s}$ as an 'autonomous secularist grassroots movement ${ }^{37}$ in response to the rising power of the Islamist-oriented Welfare Party (RP, Refah Partisi). In the 1994 municipal elections, the RP won most of the major city administrations and placed Recep Tayyip Erdoğan, the present Prime Minister of Turkey, as the first Islamist mayor of Istanbul. Unprecedentedly, secularist groups reacted to the perceived Islamist threat via circulating the 'blacklist' of all businesses providing support to the RP, publishing new local newspapers, and founding NGOs. As a counter-balance to the success of the RP's grassroots organizations, several associations were established, such as the Support for Modern Life Association (ÇYDD, Çă̆daş Yaşamı Destekleme Derneğ i) and the Modern Writers Association (ÇYD, Çăgdaş Yazarlar Derneği). The word modern (çăgdaş) was used synonymously with secular. ${ }^{38}$ While the ÇYDD founded 'houses of learning' in shanty-towns around Istanbul to ground the revived Kemalism in society, ${ }^{39}$ the Turkish Women's Association, with help from the military, launched a 'Movement for Youth against Fanaticism.'40

The increasing visibility of political Islam led to the revitalization of the official ideology. The most notable embodiment of this Kemalist enthusiasm was in the 1998 celebration for the seventy-fifth Republic Day anniversary that commemorates the declaration of the Turkish Republic on October 29, 1923. Unlike the routine stateorganized celebrations in earlier years, secularist civil society organizations coordinated unconventional demonstrations and festivals in city squares 'to make an anti-Islamist

35 B. Toprak (1981) Islam and Political Development (Leiden: E. J. Brill), pp. 36-48.

36 N. Göle (1996) Authoritarian Secularism and Islamist Politics: The Case of Turkey, in: A. R. Norton (ed.) Civil Society in the Middle East, pp. 17-43 (Leiden: E. J. Brill), p. 35.

37 A. Çınar (2005) Modernity, Islam, and Secularism in Turkey: Bodies, Places, and Time (Minneapolis: University of Minnesota Press), p. 20.

${ }^{38}$ Ibid. pp. 19-20.

39 Y. Navaro-Yashin (1998) Uses and Abuses of 'State and Civil Society' in Contemporary Turkey, New Perspectives on Turkey, 18, pp. 1-22, p. 16.

40 M. Howe (1997) Secularists Won First Round Without Bloodshed, But Islamists Expect Victory in 1998 Election, The Washington Report on Middle East Affairs, 16(4), December 31, 1997, pp. 31-33, p. 31. 
statement. ${ }^{41}$ This celebration is important as it followed the 1997 military intervention, known as the 'February 28 Process,' that suppressed a democratically elected Islamist government and later gave way to the closure of the RP for acting as the 'focal point of anti-secularist activities. ${ }^{42}$ There was 'a widespread belief among the secular-urbanities that the intensity of the Islamic threat may require the suspension of democratic freedoms and limitation of representative principles and institutions. ${ }^{43}$ In this regard, the 1998 celebrations expressed not only a show of force against the 'Islamist threat' and ethnic separatism, but also came to legitimate the military intervention and the secular regime. They illustrated how the state and the society were fused to each other against the perceived threats of political Islam and Kurdish separatism. On the sites of the celebrations, "it is not easy to empirically distinguish between what was "the state" and what was "society.", 44

In the official declaration of the National Security Council Meeting of February 28, 1997 that also gave name to the following process, the military justified its intervention into normal politics by reiterating Turkey's commitment to full EU membership and "presenting secularism as "a guarantee not only for the regime but at the same time of democracy.", 45 Accordingly, the military's long-term project to reshape the Turkish political and social system was not some sort of deviation from Turkey's EU project. On the eve of the second millennium, however, it was not so easy to reconcile the secularist enthusiasm with the EUoriented democratization process. The secularists, the long aspirers of Westernization, came to show reluctance toward Turkey's decades' long-held dream, ie full membership in the EU. ${ }^{46}$ Indeed, some liberal secular organizations, such as the Turkish Industrialists' and Businessmen's Association (TÜSİAD, Türkiye Sanayicileri ve İsadamları Derneği) and the Economic Development Foundation (İKV, Íktisadi Kalkınma Vakfi), have been among the most active pressure groups forcing the governments to hasten the EU-related reforms. Yet, 'not all business associations are equally enthusiastic' about the process. The Union of Chambers and Commodity Exchanges of Turkey (TOBB, Türkiye Odalar ve Borsalar Birliği) and the Turkish Confederation of Employer Associations (TISSK, Türkiye Issveren Sendikaları Konfederasyonu) are two examples showing a 'somewhat lukewarm attitude' toward the EU project, ${ }^{47}$ while many labor unions, such as Türk-Metal and Türk-İş, are openly against the accession process.

Ironically, after 2002, the Westernist pro-EU discourse shifted to the ruling conservative government of the Justice and Development Party (AKP, Adalet ve

${ }^{41}$ E. ÖÖzyürek (2006)zyürek (2006) Nostalgia for the Modern: State Secularism and Everyday Politics in Turkey (Durham: Duke University Press), pp. 125-150.

42 On February 28, 1997, the National Security Council, composed of military and civilian leaders, issued a list of 18 'recommendations' imposed on the government and justified by the need to prevent the assumed Islamicization and preserve the secular regime. This led not only to the downfall of the coalition government and the dissolution of the RP, but also to the rearrangement of the parameters of political and social life in line with secularism.

43 Ü. Cizre \& M. Çınar (2003) Turkey 2002: Kemalism, Islamism, and Politics in the Light of February 28 Process, The South Atlantic Quarterly, 102(2/3), pp. 309-332, p. 322.

${ }^{44}$ Navaro-Yashin, Uses and Abuses, pp. 19-20.

45 Cizre \& Çınar, Turkey 2002, p. 314.

46 Altınay \& Nicolaidis, European Union strengthens Turkish secularism.

47 Z. Öniş (2003) Domestic Politics, International Norms and Challenges to the State: Turkey-EU Relations in the Post-Helsinki Era, Turkish Studies, 4(1), pp. 9-34, p. 33, fn 21. 
Kalkınma Partisi), an offspring of the Islamist RP. According to the secularists, the EU's reform demands in line with the acquis communautaire, ${ }^{48}$ such as balanced civil-military relations, rights for ethnic and religious minorities, and strengthening freedom of expression, will destroy the national unity and territorial integrity of Turkey. Moreover, diminishing the role of the military, the self-assigned guardian of the secular regime, and further political liberalization can strengthen political Islam, and this eventually could lead to a shariah-based rather than a European state. Expectedly, the 'pro-Kemalist' organizations 'enforcing the restoration of the existing legal-institutional framework along the lines of laicism, modern life, national unity, and nationalism' do not enthusiastically support all democratization reforms, ${ }^{49}$ as change in the political structure has threatened the Kemalist status quo. This polarized context, in which support for EU membership is identified with adherence to the AKP, even led many of the liberal seculars, let alone the hard-line secularists, to refrain from giving fully-fledged support to the EU project, as they used to do until 2002. Pioneers of EUism, like TÜSİAD, started to loosen their fullyfledged support and stated that Turkey should not jump into the union. They felt the need to remind members and the public of their commitment to secularism and Turkish nationalism. $^{50}$

This cautious stance toward democratization reforms also led some secular elites to search for alternative paradigms, such as Euroasianism, which offers forming political, economic, and military alliances with Turkey's eastern neighbors, Russia and Iran, as well as with China and the Turkic countries in Central Asia. ${ }^{51}$ General Tuncer Kılıç, former Secretary-General of the National Security Council, was the first state elite who openly expressed this search. Addressing the military academy at a conference in 2002, he suggested that Turkey should seek new alliances instead of membership in the EU. Five years later, Kılıç even proposed leaving NATO. ${ }^{52}$

Different from typical Euro-skepticism in other candidate countries, a secularist nationalism called ulusalcilık has developed based on fears about the unitary and secular character of the regime. ${ }^{53}$ In this calculation, the liberalization reforms as part of the EU Harmonization process just recalls Sèvres, the treaty proposing the partition of the Ottoman Empire based on ethnic communities after its defeat in World War I. ${ }^{54}$ The treaty, which offered the founding of Armenian and Kurdish states in Anatolia, was never put into effect but was replaced by the 1923 Treaty of Lausanne, which recognized the unitary existence of the Turkish Republic. Nevertheless, Sèvres turned into a syndrome

48 The acquis are the set of norms and legal provisions that exist among the EU member states and are set as the membership criteria to be fulfilled by the candidate countries.

49 N. Erdoğan (2000) Kemalist Non-governmental Organizations: Troubled Elites in Defence of a Sacred Heritage, in: S. Yerasimos, G. Seufert \& K. Vorhoff (eds) Civil Society in the Grip of Nationalism, pp. 251282 (Istanbul: Orient-Institut): 252.

50 TÜSİAD' dan Hükümete Laiklik Uyarısı [TÜSİAD warns the government on secularism], Milliyet, September 21, 2007.

51 E. Akçalı \& M. Perinçek (2009) Kemalist Euroasianism: An Emerging Geopolitical Discourse in Turkey, Geopolitics, 14(3), pp. 550-569, p. 551.

52 S. Özel, S. Yılmaz \& A. Akyüz (2009) Re-building a Partnership: Turkish-American Relations for a New Era-A Turkish Perspective (Istanbul: TÜSİAD), p. 31.

53 B. Taraktaş (2008) A Comparative Approach to Euroscepticism in Turkey and Eastern European Countries, Journal of Contemporary European Studies, 16(2), pp. 249-266.

54 Akçalı \& Perinçek, Kemalist Euroasianism, p. 553. 
among secularists who have continued to view Turkey as being in a constant state of insecurity. The Sevres Syndrome, on the one hand, nurtured isolationist and antiWesternist tendencies in the form of the widespread conviction that Turkey is encircled by enemies trying to divide up the country; on the other hand, it justified the elimination of any alternative views, such as Kurdish nationalism and political Islam, representing them as a danger to national security and territorial integrity. In this regard, the Kemalist hardliners posit themselves as 'national forces without uniforms' determined to save the country from internal and external enemies, following the "national forces in uniforms. ${ }^{55}$ Reminiscent of the Associations for the Defense of Rights (Müdafa-i Hukuk Cemiyetleri) and the para-military groups called National Forces (Kuvayı Milliye), which launched Turkey's Independence War (1919-22), several organizations have been established with similar names, such as the National Forces Society, the Association for the Defense of Rights Once More, and the Patriotic Front. Their objective has been to start a war of independence against the cooperation of the Western imperialists and their collaborators, i.e. the AKP government.

In addition to the women's organizations that had appeared in the 1990s, these new associations now also advocated for a secularist revival. Yet, what makes them civil is vague. Some of these civil societal organizations could expand and make demonstrations via the financial support and facilities of the state. This kind of support ranges from state officials' appearance in their organizations to financial aid, like former President Necdet Sezer's TL100,000 donation to the Association of Atatürkist Thought (ADD, Atatürkçü Düşünce Derneği $).{ }^{56}$ Moreover, these organizations mostly are formed or run by former military officers who maintained their militarist approach, such as Retired Colonel Fikri Karadağ, the head of the National Forces Society, and Retired Lieutenant General Hasan Kundakç1, the honorary chair of the Union of Power of Patriotic Forces. ${ }^{57}$ Nevertheless, their capacity cannot be compared to that of the Association of Atatürkist Thought (ADD), run at the time of the rallies by ex-General Şener Eruygur.

The Republic Rallies, initially led by the ADD, and later also pioneered by the ÇYDD, the Association of Republican Women, and other women-led NGOs, are the most obvious manifestation of this secularist response to the changing texture of political and social life in Turkey. ${ }^{58}$ According to Göle, the rallies were a 'feminine coup,' and 'the main actors

55 Erdoğan, "Kemalist Non-governmental Organizations, p. 267.

56 In an interview she gave to a website in April 2012, Tansel Colasan, current head of ADD, testifies to the financial and organizational support that ADD received from state organs. For the full interview, see O. Zafer Ceylan (2012) Tansel Çölaşan: Kılıçdaroğlu'nun Atatürkçülüğünden Emin Değilim [Tansel Çölaşan: I am not sure about how Kemalist K1lıçdaroğlu is], Son Kulis, April 18. Available at http://www.sonkulis.com/roporta j/add-baskani-tansel-colasan-sonkulise-konustu-kilicdaroglunun-ataturkculugunden-emin-degilim-h3096. html, accessed April 24, 2012. Of the YTL113,000 donations collected by ADD in year 2006, YTL100,000 has been provided by the budget of the presidential office. See ADD'nin Resmi Sponsoru Ahmet Necdet Sezer [ADD's Official Sponsor Ahmet Necdet Sezer], Zaman, July 13, 2008.

57 As a radical manifestation of the militarist approach, Fikri Karada $\breve{g}$ initiated in the oath-taking ceremonies for the members of the organization to swear that they are ready to kill and be killed: 'I am of pure Turkish stock without any Jewish convert in my blood. We can die for this cause, we can be murdered, we can murder ... for the sake of making the Turkish nation the lord of the world." İ. Saymaz (2007) 'Vatanseverlik' yarışındaki örgütler emekli asker dolu [Organizations competing for 'Patriotism' are Full of Retired Soldiers], Radikal, February 17, 2007.

58 Yüzbinler Çağlayan'a aktı [Hundreds of thousands of people streamed to Çağlayan], Hürriyet, April 29, 2007. 
are the female citizens who worry about the shift in the axis of the laic state. ${ }^{59}$ These unprecedentedly massive rallies, organized in April and May 2007 mostly in major Turkish cities, were protesting the possible victory of the AKP in the presidential elections to be held in parliament. The women participants believed that the AKP controlling the government, the parliament and now the presidency would be strong enough to implement its hidden agenda and bring shariah rule.

Meanwhile, in late April 27, 2007, the General Staff weighed in on the presidential election process in an extraordinarily harsh statement on its website. Called an 'e-memorandum,' it reminded readers of its position as the defender of the secular state: 'It should not be forgotten that the Turkish Armed Forces is a party in this debate and is a staunch defender of secularism. When necessary, it will display its attitudes and actions very clearly. No one should doubt that. ${ }^{60}$ Exactly like the $75^{\text {th }}$ Republic Day celebrations that legitimated the 1997 intervention of the military, the Republic Rallies seemed to have approved the military's statement. ${ }^{61}$ During the rallies, the then vice-president of ADD, Nur Serter, declared that

In contrast to the mentality calling the Chief of the General Staff a 'civil servant', we respectfully bow in front of our glorious Turkish army. The Turkish army proclaimed our voice on April 27, and protected the secular republic and democracy. We will not let the Turkish army be slandered. ${ }^{62}$

Initially, the name of the rallies, 'the Republic Rallies,' demonstrated the efforts to unite people under this pro-secular umbrella, to show the masses in the rallies as the true nation, and to eliminate any possible opposition to the rallies beforehand. The fact that these meetings are called 'Republic Rallies' shows they are by definition all-inclusive, ie meant to include the whole nation, thereby assuming the authorial voice of the totality of the Turkey. This framing of the meetings rules out attempts to criticize or contest them, because doing so would mean that the Republic and its founding principles are themselves contested. Accordingly, those who claim to love their Republic are expected to join these protests and to protect it against its enemies.

The excessive use of the Turkish flag at the meetings is the main symbol of the demonstrations around which all participants rally and also signifies the same totalizing nationalist discourse. The flags of political parties were not allowed in the demonstration areas, the meeting areas or the surrounding apartment buildings, and even the cars passing by were all decorated with the Turkish flag. Being an uncontestable symbol of the Turkish nation, the flag also helped to frame the Republic Rallies and the message as uncontestable

\footnotetext{
59 N. Göle (2007) Sokak ve Cumhuriyet: 'Nümayişkar' Feminen Darbe [Street and republic: 'Pretentious' feminine coup], Radikal, May 1, 2007.

${ }^{60}$ Excerpts of Turkish army statement, Turkish Daily News, April 30, 2007.

61 Türkan Saylan, the then head of ÇYDD, took a more democratic stance and popularized the motto 'Neither coup, nor Shariah!,' but she was not allowed to address the audience in the following rallies. See B. Oran (2009) Türkan Hoca'nın evi niye arandı? [Why was Professor Türkan's house investigated?], Radikal 2, May 3, 2009. Nevertheless, Türkan Saylan also approved the military's e-memorandum. See A. Arman (2007) Annem ve ben birbirimizin zıddı iki kadındık [We, mom and me, were opposite women], Hürriyet, May 6, 2007.

${ }^{62}$ Çağlayan'da bayrak denizi [The sea of flags in Çağlayan], Milliyet, April 29, 2007.
} 
truths of the Turkish nation. This turns any alternative view into a separatist or reactionary threat posed to the republic. As a consequence of this asserted monopoly on the definition of the nation, those who contested the Republic Rallies and criticized similar protest activities were framed as having taken a stance against efforts to protect and defend the Republic and its core values, and hence were treated as traitors. Criticism directed at the Republic Rallies in particular and the secularist nationalists in general were placed in the same category of separatist or reactionary threats to the Republic, even if they came from liberal secular circles.

Furthermore, the speeches made and slogans chanted throughout the demonstrations were presented as reflecting the general will of Turkish society. When pronouncing in the demonstrations 'The people will prevail!' or 'United Turkey, ${ }^{63}$ the participants assumed themselves to be representing the whole of Turkey. Indeed, the secularist NGOs that organized the meetings claimed to represent all of Turkey and to speak on behalf of the whole nation. Carrying anti-AKP banners and pictures of Atatürk, the participants expressed their determination to defend the country against political Islam. The participants also generally used a language similar to the slogans used by those who fought during the Independence War. Carrying anti-government banners and pictures of Atatürk, the protestors showed their determination 'to defend' the country. ${ }^{64}$ Some protestors declared that 'These rallies must continue until there is no longer a threat,' while others considered themselves to be 'the soldiers of Mustafa Kemal' and marched in the rallies to 'defend' his revolution. ${ }^{65}$

Their defense was against the Islamists inside the country, ${ }^{66}$ and the Western powers outside. 'We don't want an imam as president ... Our message is clear: we are telling Gül not to be a candidate,' the protestors chanted in the rallies. ${ }^{67}$ Their reference was to Abdullah Gül, the second man of the AKP, whom they believed should not be selected for the presidency because he had an Islamist background and his wife wore a headscarf. Moreover, crowds chanting 'Neither EU, nor USA, Fully independent Turkey!' showed their dislike of the foreign pressures they perceived as direct interventions into domestic politics. The Kemalist motto 'Full Independence!' in this framing might even refer to severing external ties with the EU and the United States, as well as suppressing political Islam and Kurdish nationalism inside the country. These slogans are evidence that the hard-line secularists are no longer content with the Westernization project and its consequences. Even though they use democratic forms of opposition, they are quite cautious about enhancing democratization. The irony is that what they fear is, indeed, what they do: If they cannot suppress the rise of political Islam, they think the Islamists will suppress them.

Since 2006, Kemalism has been associated with terrorism for the first time in Turkish political history. In that year, police revealed that 14 cell-type military gangs had formed 'to save the country from the threat of an Islamist government and EU imperialism.' An

\footnotetext{
${ }^{63}$ S. Ranisford (2007) Battle Begins for Turkish Parliament, BBC News, May 15, 2007.

64 Ibid.

65 S. Fraser (2007) Secular Turks Hold Demonstration, The Guardian, May 13, 2007.

${ }^{66}$ Although the rallies called for unity to save the Republic, their rhetoric also excluded the Kurdish groups, and Kurdish identity was totally invisible in the rallies. Slogans like 'No sub- and supra-identity! Happy is the one who says I am Turk!' showed the disapproval with enhancing ethnic minority rights.

67 'Cumhurbaşkanı olma' mitingi ['Don't be the president' meeting], Hürriyet, April 15, 2007.
} 
investigation into this ultra-nationalist network, called Ergenekon, began in June 2007. The Ergenekon network differs from earlier formations in both the high profile of the members and the extent of its activities. ${ }^{68}$ According to the indictments, the Ergenekon was led by some senior military commanders, political leaders, and intellectuals who tried to sow chaos and civil unrest through political murders and by supporting civil societal protests, including the Republic Rallies and the anti-EU associations mentioned above, so that the army would intervene in politics to topple the ruling AKP government. Following the Ergenekon indictments, several other indictments investigating consequent plots against the Islamist government were presented. According to these indictments, all the plot attempts rely on the active use of civil society organizations in order to create a political climate appropriate for a military takeover. ${ }^{69}$

How could secular Turkish civil society come to oppose further democratization? This research connects this situation to civil society's stance toward the state, rather than its ideological leaning. In the Turkish case, two factors come forward: the pragmatic and the state-centered approach to democracy and secularism as part of the founding ideology and status quo.

\section{Priority of Secularism and the State}

Democracy never has been a sine qua non for Turkey's state-centered politics. The secular establishment promoted democracy as part of the Kemalist Westernization project but did not hesitate to suspend democracy whenever it was perceived as threatening secularism. The Free Party (Serbest Fırka) experience in 1930, which was Atatürk's most important step toward democracy, illustrates this conditional support. Atatürk realized that the single-party system became 'a sign of Turkey's inferiority in comparison with Europe and the West,' as Western observers often described the Republic as the 'Turkish dictatorship,' one that was 'Western in form but Oriental in fact. ${ }^{70}$ Consequently, he invited his friend Fethi Okyar to found a 'loyal' opposition party. Atatürk also ensured that the new party would be safe as long as it stayed within the secular republican framework. Nevertheless, Okyar's Free Party soon appealed to huge segments of the society and was considered as a platform to show their reaction to the regime. The party meetings, especially the one in İzmir, turned into violent counter-revolutionary protests. Due to the pressure of the ruling CHP members and Atatürk's withdrawal of support, Okyar declared the dissolution of the Free Party. The de facto one-party rule continued until 1950, when the Democrat Party (DP-Demokrat Parti) came to office after general elections. Since then, the military has interrupted Turkish democracy almost every decade whenever it perceived a threat to the main tenets of the regime.

${ }^{68}$ H. Taş, Will Turkey Benefit from Turkey, Le Monde Diplomatique, November 18, 2009. Available at http:// mondediplo.com/blogs/will-turkey-benefit-from-ergenekon, accessed February 7, 2010.

69 For a summary of the indictments, see The Open Source Center Report (2010) Turkey-Guide to Ergenekon, March 19, 2010; see also the special issue guest-edited by A. Balci \& T. Jacoby (2012) The Ergenekon Counter-Terrorism Investigation in Turkey: Representations and Implications, Middle East Critique, 21(2), pp. 135-225.

70 W. Weiker (1973) Political Tutelage and Democracy in Turkey: The Free Party and its Aftermath (Leiden: E. J. Brill), p. 58. 
More provocatively, one may argue that despite its ideological value within the founding ideology, secularism was not the absolute target for the Turkish state elite, either. As Nikki Keddie says, 'secularization in the Middle East is inseparable both from westernization and from efforts to strengthen the central state. ${ }^{, 71}$ It was instrumental for a larger aim: Westernization. The Kemalist reforms connected to secularism principally were aimed at bringing Turkey to the status of the advanced states of the world. Atatürk envisaged his ultimate goal for the nation as reaching to the level of contemporary civilization, which was the Western civilization. ${ }^{72}$ Neither democracy nor secularism was initiated as a solution to the political conflicts in Turkey, but was part of the imposed Westernization process. Westernization has also been considered to serve another ultimate aim: the survival of the state. Westernization was the answer to the default question of the late Ottoman elite: how to save the state. The nineteenth-century Ottoman Empire, having lost much of its territories and strength, did not hesitate in the Westernization process instead of other ideological orientations, such as Pan-Ottomanism and Pan-Islamism. The Republican elite, who were Ottoman pashas, tried to westernize the country to maintain and strengthen the state. In short, secularism and democracy, two norms, which the West developed after long struggles and due to political and social needs, were introduced in Turkey by the state and for the state. This explains why both can be interrupted by the state. The recent uneasiness in secularist circles with the democratization reforms can make sense only when taking this state tradition into consideration. Democracy can be suspended whenever a threat occurs to secularism, a pillar of the regime. It is this mentality behind the secularists' cri de coeur, such as 'We do not need democracy, but the republic.'

The Turkish Republic inherited from the Ottoman Empire a strong state tradition in which the 'transcendental' nature of the state requires that community and the state take precedence over their members. ${ }^{73}$ In this line, modern Turkey maintained a communitarian approach to citizenship ${ }^{74}$ that is based on a monolithic conception of society and denies recognizing any particularities in the name of national solidarity. The primacy of secularism over democracy signifies the state's predominance over the individual and now is being challenged by liberal notions of citizenship.

\section{Secularism as Part of the Founding Ideology}

The main merit of civil society is held to be as a balance to state power. Civil society helps democratization as long as it protects an area of plurality in which the state does not intrude. This is an inclusive realm of particular interests; however, ideological affinity with state institutions may convert the democratic potential of civil society organizations. Yet we are not claiming that civil society organizations that have similar ideological values to those of state institutions will necessarily harm democratization; rather we would like to point out that with this ideological affinity, civil society organizations might lose

\footnotetext{
${ }^{71}$ N. R. Keddie (1997) Secularism and the State: Towards Clarity and Global Comparison, New Left Review, 226, pp. $21-40$, p. 28.

72 T. Timur (1968) Türk Devrimi-Tarihi Anlamı ve Felsefi Temeli [The Turkish revolution-Its historical meaning and philosophical background] (Ankara: Ankara Universitesi SBF), p. 96.

73 M. Heper (1985) The State Tradition in Turkey (Walkington: Eothen Press), pp. 7-8, 16.

74 E. F. Keyman \& A. Icduygu (eds) (2005) Citizenship in a Global World: European Questions and Turkish Experiences (New York: Routledge).
} 
their independence vis-à-vis the state. Moreover such ideological proximity might lead some civil society organizations to perceive themselves as the carriers of the common good rather than particular interests, and to project civil society as an exclusive realm. This is the problem of many civil society organizations with secular leanings in Turkey.

Both the critics and defenders of Turkish modernization would agree that it was a topdown project, ${ }^{75}$ further radicalized by the tradition of a transcendental state. The radical reforms taken by the Kemalist establishment were not the result of any popular demands. Instead, it was an elite-designed transformation of the whole state and society according to their blueprint of 'Western modernity.' Secularism was the central part of this transformation. Kemalist 'secularism' was meant to represent 'progress' and 'civilization' against alleged Islamic 'backwardness' and 'Oriental barbarism. ${ }^{76}$ Thus, from the very beginning 'secularism ceased to denote just the separation of state and religion in Turkey but instead became a virtual creed. ${ }^{, 77}$ This sacred status of secularism is also reflected in the entrenchment of secularism in the constitution. Among many secular countries all around the world, Turkey is among the few countries where secularism is a constitutional principle and, aside from Tunisia, the only Muslim country as such. According to the second article of the current constitution, secularism is among the three characteristics that define the Turkish Republic. Moreover secularism is emphasized further by the irrevocability of the related article of the constitution.

Taking into consideration that secularism from the beginning was a state project and given its central importance in the ideology of the state, it is not surprising to see that even a mild questioning of secularism is considered as tantamount to high treason against the state. ${ }^{78}$ In this respect, secularists in Turkey show striking similarities with the Islamists in Iran in their attitude and the language they deployed against their opponents. Following the 2009 presidential elections in Iran, reformists organized mass protests. During these demonstrations, reformists were accused not only of being against the dominant interpretation of Islam by the regime, but also they were accused of being traitors. Moreover this was not only the discourse of the state organs, but non-official bodies with the same ideological leaning followed the same language. ${ }^{79}$ The same mindset and attitude could be followed easily during the Republic Rallies in Turkey. As we have shown already, the discourse of defending the nation against inner enemies was the common sentiment during the Republic Rallies in Turkey. Despite the fact that secularist circles in Turkey resort to violence less frequently compared with the conservatives in Iran, the discourse of defending the nation against inner enemies (and the implication that their adversaries are not only the political opposition but also are actually traitors, thus not legitimate political actors) was the common sentiment during both the Republic Rallies in

\footnotetext{
75 For a supportive assessment of Turkish modernization, see B. Lewis (1963) The Emergence of Modern Turkey (New York: Oxford University Press). For a more recent and critical review, see S. Bozdogan \& R. Kasaba (eds) (1997) Rethinking Modernity and National Identity (Seattle: University of Washington Press).

76 H. Yavuz (2003) Islamic Political Identity in Turkey (Oxford: Oxford University Press, p. 46.

77 Ibid. p. 31.

${ }^{78}$ Ibid. p. 46.

79 A report on the unrest following the elections in Iran issued by a very powerful NGO called the Isargeran (Self-sacrifice) Society is very illuminating in this respect. The report is titled 'Defeat of Velvet Revolution in Iran,' and it accuses the protestors in Iran of being infiltrators of Western powers. See The Analysis of the Self Sacrifice Society of Iran on the Failure of Velvet Revolution, Doğudan, 2(13) (2009), pp. 34-47.
} 
Turkey and the suppression of the political unrest in Iran after the 2009 elections. The political language of two completely different groups operating in different settings in the Middle East demonstrate that it is not Islam or secularism that feeds intolerance, but it is the association of a political creed with state power and state ideology that feeds intolerance. In Iran, the incorporation of Islam, as it is interpreted by the state elites, into the state ideology transforms any questioning of this dominant interpretation into a security problem; while in Turkey, even a mild questioning of (the dominant interpretation of) secularism becomes a security issue. Thus, while it is the Islamists in Iran who associate themselves with the state monopoly of truth, and thus are intolerant of any other group, in Turkey it is the secularists who associate themselves with the state monopoly of truth. Similarly, just as the conservatives in Iran identify any challenge against themselves with treason, so do the secularists in Turkey.

Re-considering Gellner's claim that Islam, and Marxism he also adds, is unsuitable for a democratic civil society since it claims the monopoly of truth, we can claim easily that in the Turkish case, the monopoly of truth lays in the hands of secularists. Based on the conception of civil society as the realm of particularity, Gellner's assumption that any claim on the monopoly of truth will necessarily undermine civil society is correct. What is wrong in his assumption is equating such a monopoly with religion. In fact, especially in societies that experience top-down modernization, it is always the state that claims the monopoly of truth. Thus, it is not secularism or Islam that undermines or threatens civil society; it is the association with the state ideology that undermines civil society. Secularists in Turkey who identify themselves with the state ideology and the conservative Islamists in Iran both challenge the democratic potential of civil society.

\section{Conclusion}

Observers of Turkish politics can realize easily the political re-alignments since 2000. As Ahmet İnsel points out, 'Turkey is now going through a paradoxical period in which statist-Westernizing elites are forced to swerve into anti-Western positions, and the West is defended by Islamic, Kurdish, and other movements of identity politics. ${ }^{80}$ In the case of Turkish civil society, the secularist NGOs have strong pro-state tendencies and they support unity against particularism. However, two basic features are essential for civil society to help democratization: The position of civil society as the opposite of the state, and the particularistic nature of civil society as different groups pursue their own benefits. Particularism gains importance as a prerequisite of plurality. Organizations that are not autonomous from the state turn either to corporatist organizations or mechanisms for the oppressive state to control society. The pro-state youth clubs of the Nasser regime in Egypt are a good example for this. ${ }^{81}$ Moreover, those organizations that align themselves with hegemonic ideologies rather than pursue their particular interests and also claim a discursive monopoly of truth become less tolerant and not inclined to compromise.

\footnotetext{
80 A. Insel (2003) The AKP and the Normalizing of Democracy in Turkey, South Atlantic Quarterly, 102(2/3), pp. 293-308, p. 306.

81 For an analysis of these youth clubs, see Y. Di-Capua (2004) Sports, Society, and Revolution: Egypt in the Early Nasserite Period, in: E. Podeh \& O. Winckler (eds) Rethinking Nasserism (Gainesville: University Press of Florida), pp. 144-162.
} 
We posit that it is not a matter of being secular or Islamic but of plurality versus totality. Literature in the Western context, following Hegel, accepts the particularistic and egoistic character of civil society as given, concentrates on the coordination and reconciliation of the clashes of these particularistic interests and the state. However, in societies witnessing top-down modernization, fragments of the society, which are foremost modernizers, may claim the monopoly of the ultimate reason (of the Hegelian state). These groups act in the name of the common good thus leaving no space for particularization and diversification of interest. With their monopoly on the ultimate truth, these groups show little tolerance toward 'other' groups in society. It would not be an exaggeration to claim that the discussion on civil society and democratization in the Middle East is misplaced in the secularism-Islam nexus. Indeed, attention should be focused on the issues of plurality versus totality. As the Turkish case demonstrates, the totalistic and intolerant character of civil society in the Middle East does not necessarily stem from its Islamic character. In fact, the major impediments to democratization are the non-existence of particularity and the anti-state features of civil society.

\section{Acknowledgements}

We would like to thank Abdulkadir Yildirim, Ilknur Murphy and Ozge Genc for their comments on earlier drafts of this article. Needless to say, the responsibility for the views presented here are solely ours.

\section{References}

Abootalebi, A. (1998) Civil Society, Democracy and the Middle East, Middle East Review of International Affairs, 2(3), pp. 46-59.

Akçalı, E. \& Perinçek, M. (2009) Kemalist Euroasianism: An Emerging Geopolitical Discourse in Turkey, Geopolitics, 14(3), pp. 550-569.

Akman, N. (2005) Emekli General Nejat Eslen: Deomkrasi, Türkiye'nin öncelikli meselesi değil [Retired General Nejat Eslen: Democracy is not a priority for Turkey], Zaman, July 18.

Akyol, M. (2005) Ulusalcılarımızın Çıkarları [The Interests of Our Nationalists], Radikal, September 30.

Altınay, H. \& Nicolaidis, K. (2008) Why the European Union Strengthens Turkish Secularism, Open Democracy, August 3. Available at http://www.opendemocracy.net/article/the-european-union-and-turkey-str engthening-secularism, accessed January 5, 2009.

Arman, A. (2007) Annem ve ben birbirimizin zıddı iki kadındık [We, mom and me, were opposite women], Hürriyet, May 6.

Balci, A. \& Jacoby, T. (eds) (2012) The Ergenekon Counter-Terrorism Investigation in Turkey: Representations and Implications, Middle East Critique, 21(2), pp. 135-225.

Berman, S. (2003) Islamism, Revolution and Civil Society, Perspectives on Politics, 1(2), pp. $257-272$.

Bozdogan, S. \& Kasaba, R. (Eds) (1997) Rethinking Modernity and National Identity (Seattle: University of Washington Press).

Browers, M. L. (2006) Democracy and Civil Society in Arab Political Thought: Transcultural Possibilities (Syracuse, NY: Syracuse University Press).

Cavatorta, F. (2006) Civil Society, Islamism and Democratization: The Case of Morrocco, Journal of Modern African Studies, 44, pp. 203-222.

Cavatorta, F. \& Durac, V. (2011) Civil Society and Democratization in the Arab World: The Dynamics of Activism (New York: Routledge).

Ceylan, O. Z. (2012) Tansel Çölaşan: Kılıçdaroğlu'nun Atatürkçülüğünden Emin Değilim [Tansel Çölaşan: I am not sure about how Kemalist Kılıçdaroğlu is], Son Kulis, April 18. Available at http://www.sonkulis. com/roportaj/add-baskani-tansel-colasan-sonkulise-konustu-kilicdaroglunun-ataturkculugunden-emin-degil im-h3096.html, accessed April 24, 2012.

Cizre, Ü. \& Çınar, M. (2003) Turkey 2002: Kemalism, Islamism, and Politics in the Light of February 28 Process, The South Atlantic Quarterly, 102(2/3), pp. 309-332. 
Çınar, A. (2005) Modernity, Islam, and Secularism in Turkey: Bodies, Places, and Time (Minneapolis: University of Minnesota Press).

Diamond, L. (1994) Rethinking Civil Society: Toward Democratic Consolidation, Journal of Democracy, 5(3), pp. $4-17$.

—. (1999) Developing Democracy Towards Consolidation (Baltimore: Johns Hopkins University Press).

Di-Capua, Y. (2004) Sports, Society, and Revolution: Egypt in the Early Nasserite Period, in: E. Podeh \& O. Winckler (Eds) Rethinking Nasserizm (Gainesville: University Press of Florida), pp. 144-162.

Doğudan (2009) The Analysis of the Self Sacrifice Society of Iran on the Failure of Velvet Revolution, 2(13), pp. 34-47.

Encarnación, O. G. (2006) Civil Society Reconsidered, Comparative Politics, 38(3), pp. 357-376.

Erdoğan, N. (2000) Kemalist Non-governmental Organizations: Troubled Elites in Defence of a Sacred Heritage, in: S. Yerasimos, G. Seufert \& K. Vorhoff (Eds) Civil Society in the Grip of Nationalism (Istanbul: Orient-Institut), pp. 251-282.

Esposito, J. L. \& Voll, J. O. (1996) Islam and Democracy (New York: Oxford University Press).

Fraser, S. (2007) Secular Turks Hold Demonstration, The Guardian, May 13, 2007.

Gellner, E. (1981) Muslim World (Cambridge: Cambridge University Press). (1994) Conditions of Liberty: Civil Society and Its Enemies (New York: Penguin).

Göle, N. (1996) Authoritarian Secularism and Islamist Politics: The Case of Turkey, in: A. R. Norton (Ed.) Civil Society in the Middle East (Leiden: E.J. Brill), pp. 17-43.

- (2007) Sokak ve Cumhuriyet: 'Nümayişkar' Feminen Darbe [Street and Republic: 'Pretentious' Feminine Coup], Radikal, May 1.

Hawthorne, A. (2004) Middle Eastern Democracy: Is Civil Society the Answer?, Carnegie Papers 44 (Washington D.C. Carnegie Endowment for International Peace).

Heper, M. (1985) The State Tradition in Turkey (Walkington: Eothen Press).

Howe, M. (1997) Secularists Won First Round Without Bloodshed, But Islamists Expect Victory in 1998 Election, The Washington Report on Middle East Affairs, 16(4), pp. 31-33.

Hürriyet (2003) 'Ordu Göreve' DGMlik oluyor ['Army, Do Your Duty' brought to the National Security Court], November 4.

Hürriyet (2007a) 'Cumhurbaşkanı olma' mitingi ['Don't be the President' Meeting], April 15.

Hürriyet (2007b) Yüzbinler Çağlayan'a aktı [Hundreds of thousands of people streamed to Çağlayan], April 29.

Ibrahim, F. \& Wedel, H. (1997) Introduction, in: F. Ibrahim \& H. Wedel (Eds) Ortadoğu'da Sivil Toplumun Sorunlarl, [Problems of Civil Society in the Middle East] (Istanbul: Iletişim), pp. 00-01.

Insel, A. (2003) The AKP and the Normalizing of Democracy in Turkey, South Atlantic Quarterly, 102(2/3), pp. 293-308.

Jamal, A. A. (2007) Barriers to Democracy: The Other Side of Social Capital in Palestine and the Arab World (Princeton, NJ: Princeton University Press).

Keddie, N. R. (1997) Secularism and the State: Towards Clarity and Global Comparison, New Left Review, 226, pp. $21-40$, p. 28.

Keyman, E. F. \& Icduygu, A. (Eds) (2005) Citizenship in a Global World: European Questions and Turkish Experiences (New York: Routledge).

Kuru, A. (2009) Secularism and State Policies Toward Religion: The United States, France and Turkey (Cambridge: Cambridge University Press).

Lakoff, S. (2004) The Reality of Muslim Exceptionalism, Journal of Democracy, 15(4), pp. 133-139.

Lewis, B. (1963) The Emergence of Modern Turkey (New York: Oxford University Press).

Linz, J. \& Stepan, A. (1996) Problems of Democratic Transition and Consolidation: Southern Europe, South America, Post-Communist Europe (Baltimore: Johns Hopkins University Press).

Mardin, Ş. (1995) Civil Society and Islam, in: J. Hall (Ed.) Civil Society: History, Theory, Comparison (Cambridge: Polity Press), pp. 278-300.

Milliyet (2007a) Çağlayan'da bayrak denizi [The sea of flags in Çağlayan], April 29.

Milliyet (2007b) TÜSİAD'dan Hükümete Laiklik Uyarısı [TUSIAD warns the Government on Secularism], September 21.

Navaro-Yashin, Y. (1998) Uses and Abuses of 'State and Civil Society' in Contemporary Turkey, New Perspectives on Turkey, 18, pp. 1-22.

Nonneman, G. (2001) Rentiers and Autocrats, Monarchs and Democrats, State and Society: the Middle East Between Globalisation, Human Agency, and Europe, International Affairs, 77(1), pp. 141-162. 
Norton, A. R. (1993) The Future of Civil Society in Middle East, Middle East Journal, 47(2), pp. $205-216$.

Norton, A. R. (Ed.) (1995/1996) Civil Society in the Middle East (Leiden: Brill Academic).

Öniş, Z. (2003) Domestic Politics, International Norms and Challenges to the State: Turkey-EU Relations in the Post-Helsinki Era, Turkish Studies, 4(1), pp. 9-34.

Open Source Center Report (2010) Turkey_Guide to Ergenekon, March 19.

Oran, B. (2009) Türkan Hoca'nın evi niye arandı? [Why was Professor Türkan's house investigated?], Radikal 2, May 3.

Özel, S., Yılmaz, Ş. \& Akyüz, A. (2009) Rebuilding a Partnership: Turkish-American Relations for a New Era-A Turkish Perspective (Istanbul: TÜSİAD).

Özyürek, E. (2006) Nostalgia for the Modern: State Secularism and Everyday Politics in Turkey (Durham: Duke University Press).

Putnam, R. (1993) Making Democracy Work: Civic Traditions in Modern Italy (Princeton: Princeton University Press).

Ranisford, S. (2007) Battle begins for Turkish parliament, BBC News, May 15.

Salt, J. (2008) The Unmaking of the Middle East (Berkeley, CA: University of California Press).

Sariolghalam, M. (1997) Prospects for Civil Society in the Middle East: An Analysis of Cultural Impediments, in: E. Özdalga \& S. Persson (Eds) Civil Society Democracy and the Muslim World (Istanbul: Swedish Research Institute), pp. 00-01.

Saymaz, İ. (2007) 'Vatanseverlik' yarışındaki örgütler emekli asker dolu [Organizations competing for Patriotism are Full of Retired Soldiers], Radikal, February 17.

Shils, E. (1991) The Virtue of Civil Society, Government and Opposition, 26(1), pp. 3-20.

Taraktaş, B. (2008) A Comparative Approach to Euroscepticism in Turkey and Eastern European Countries, Journal of Contemporary European Studies, 16(2), pp. 249-266.

Taş, H. (2009) Will Turkey Benefit from Turkey, Le Monde Diplomatique, November 18, 2009. Available at http://mondediplo.com/blogs/will-turkey-benefit-from-ergenekon, accessed February 7, 2010.

Tempest, C. (1997) Myths from Eastern Europe and the Legend of the West, Democratization, 4(1), pp. $132-144$.

Timur, T. (1968) Türk Devrimi-Tarihi Anlamı ve Felsefi Temeli, [The Turkish Revolution-Its Historical Meaning and Philosophical Background] (Ankara: Ankara Universitesi SBF).

Toprak, B. (1981) Islam and Political Development (Leiden: E.J. Brill). .(2005) Islam and Democracy in Turkey, Turkish Studies, 6(2), pp. 167-186.

Turkish Daily News (2007) Excerpts of Turkish army statement, April 30.

Valbjorn, M. \& Bank, A. (eds) (2010) The Future of Middle Eastern Political Rule Through Lenses of the Past: Revisiting the (first) Era of Post-Democratization, Middle East Critique, 19(3), pp. 181-319.

Walzer, M. (1992) The Civil Society Argument, in: C. Mouffe (Ed.) Dimensions of Radical Democracy: Pluralism, Citizenship and Community (London: Verso), pp. 89-108.

Weiker, W. (1973) Political Tutelage and Democracy in Turkey: The Free Party and its Aftermath (Leiden: E.J. Brill).

Wittfogel, K. (1957) Oriental Despotism (New Haven: Yale University Press).

Yavuz, H. (2003) Islamic Political Identity in Turkey (Oxford: Oxford University Press).

Yom, S. L. (2005) Civil Society and Democratization in the Arab World, Middle East Review of International Affairs, 9(4), pp. 14-33.

Zakaria, F. (2001) The Politics of Rage: Why Do They Hate Us? Newsweek, October 15 pp. 22-40.

.(2004) Islam, Democracy and Constitutional Liberalism, Political Science Quarterly, 119(1), pp. 1-20.

Zaman (2008) ADD'nin Resmi Sponsoru Ahmet Necdet Sezer [ADD's Official Sponsor Ahmet Necdet Sezer], July 13 .

Zubaida, S. (2001) Civil Society, Community, and Democracy in the Middle East, in: S. Kaviraj \& S. Khilnani (Eds) Civil Society. History and Possibilities (Cambridge: Cambridge University Press), pp. 232-249. 